\title{
H4C5 Gene
}

National Cancer Institute

\section{Source}

National Cancer Institute. H4C5 Gene. NCI Thesaurus. Code C115985.

This gene is involved in the formation of high order chromatin structures. 